DOI: $10.32604 / \mathrm{jrm} .2022 .017226$

$\underline{\text { REVIEW }}$

\title{
Heavy Metal Remediation in Sludge Compost: Recent Progress
}

\author{
Rongwei Xiong ${ }^{1, \#}$, Xiufang Gao ${ }^{1,2, *,}$, Xinyue $\mathrm{Tu}^{3}$, Yilin Mao ${ }^{1}$, Li Jiang ${ }^{1}$, Lu Zheng ${ }^{3}$ and Yitong $\mathrm{Du}^{3}$ \\ ${ }^{1}$ Yangtze University, Wuhan, 430100, China \\ ${ }^{2}$ Engineering Research Center of Ecology and Agricultural Use of Wetland, Ministry of Education, Jingzhou, 434025, China \\ ${ }^{3}$ School of Environmental Science \& Engineering, Hubei Polytechnic University, Huangshi, 435003, China \\ *Corresponding Author: Xiufang Gao. Email: gxf20210703@163.com \\ \#Co-first authors: Rongwei Xiong and Xiufang Gao are co-first authors of the article
}

Received: 23 April 2021 Accepted: 04 June 2021

\begin{abstract}
The safe and efficient disposal and utilization of sludge are major issues to be solved in solid waste treatment and environmental protection due to the complex characteristics of sludge and the low rate of innocuous treatments. Composting is a process of decomposing organic matter and transformed low-molecular organic acids into highmolecular humus substances under the action of microorganisms. Although land-use after composting has become an important direction for sludge treatment, heavy metal pollution is still the bottleneck problem restricting land use of sludge compost. Adding zeolite, hydroxyapatite, and other conditioning agents to the composting process affects the concentration or form of some heavy metals and effectively reduces the environmental risk. Lime and phosphorus modifiers change heavy metal speciation in samples, playing a role in decreasing biological availability and mobility. In this study, the effects of sludge composting treatment and conditioning agents on the concentrations and forms of heavy metals are reviewed. This review will provide a theoretical basis to treat heavy metals in sludge composting and lay the foundation for the land utilization and waste recycling of sludge.
\end{abstract}

\section{KEYWORDS}

Sludge compost; heavy metal; conditioning agents; remediation

\section{Introduction}

A number of environmental problems are occurring with the increase in the urban population $[1,2]$. Among these problems, sewage sludge has increased significantly, and sewage treatment technology has been developed rapidly [3]. Global sludge production is huge. For example, the output of urban sludge in China increased from 54.27 million tons to 74.36 million tons from 2010 to 2017 , with an average annual growth rate of $4.6 \%$. Sludge is a by-product of sewage treatment and an extremely complex heterogeneous body composed of organic debris, bacteria, inorganic particles, and colloids. Sludge has high water content, it easily decomposes, and it contains heavy metals, pathogens, and parasites.

Sludge treatment includes sanitary landfill, incineration, constructed wetland, composting and other methods. Sanitary landfill method has the advantages of simplicity, easy operation, low cost and strong adaptability. Although the most common method is sanitary landfilling in China, the future of sanitary landfilling is doubtful. The stability problem resulting from the poor physical nature of sludge and limited 
available landfill sites in large cities such as Shanghai and Shenzhen have become great barriers for landfill disposal [4,5]. Sludge incineration can carbonize all organic matter, kill pathogens, and minimize the volume of sludge. But its disadvantage lies in the treatment facility investment, the treatment cost is high, the equipment maintenance cost is high, the combustion will produce highly toxic substances [6]. Constructed wetland sludge treatment technology can be applied in various environmental conditions and various sludge quality. the method uses no chemicals and is low in energy and running costs, but the technology relies heavily on natural processes, which are slow and take a long time to process [7]. Composting is the most common and potential treatment technology for sludge stabilization and harmless treatment [8]. A series of physical, chemical and biological changes will occur in the process of composting, which can effectively kill pathogens, reduce the content of persistent organic pollutants and passivate heavy metals [9]. At present, incineration and landfilling are the main treatment methods for sludge in Asia and Europe, but it is difficult to use these methods for an extended period due to the risks of tail gas and groundwater pollution. However, composting can solve this problem. Composting technology has relatively low capital and operational costs, and is simple to operate efficiently [10-14].

Sludge must pass through a series of treatments to ensure the safety of the products after composting [15]. Municipal sludge includes abundant heavy metals (e.g., zinc, copper, iron, and manganese) [16-18], organic matter, nitrogen, phosphorus, and nutrient elements [19], which are excellent soil amendments and manure after composting [20,21]. The many advantages of sludge composting include improved product safety, reduced biomass quality and volume, and a reduced late carbon nitrogen ratio [22]. However, the high heavy metal content greatly restricts utilization of sludge [23,24]. Thus, the quantity of heavy metals in sludge has always been a concern [25-29]. Azari et al. [30] reported that compost concentrates or dilutes heavy metals in wastewater. Zheng et al. [31] discovered that heavy metals are converted into residual parts after composting, indicating that compost reduces biological utilization of heavy metals, and reduces the possibility that heavy metals will enter the soil during land use. SanchezMonedero et al. [32] reviewed the role of biochar as an additive in organic waste composting. Guo et al. [33] reviewed the agronomic functions of biochar as a compost additive and soil improver. Mudhoo et al. [34] described the application of composting materials to decolorize and remove dye. Soudejani et al. [35] discussed the latest developments in applying zeolite during composting of organic solid waste. These reviews focused on applying a variety of conditioning agents to sludge compost, while more recent reviews have focused on applying a single conditioning agent to sludge compost. Although some researchers have studied the removal of heavy metals from sludge compost, there is still a gap when applying different conditioning agents. Therefore, the purpose of this review is to comprehensively compare and analyze the effects of different conditioning agents on heavy metals in compost, clarify the action of the conditioning agents, and propose future research directions.

Proper composting effectively reduces heavy metal concentrations in sludge [36] to produce safe and reliable products. Fig. 1 summarizes the action mechanism and advantages of different conditioning agents in the treatment of heavy metals during sludge composting.

\section{Changes in Heavy Metal Speciation and Concentration during Sludge Composting}

Heavy metals are metals with significant biological toxicity, such as mercury, cadmium (Cd), Cr, lead $(\mathrm{Pb})$, and arsenic $(\mathrm{As})$. Heavy metals also refer to the toxic heavy metals, such as copper $(\mathrm{Cu})$, zinc $(\mathrm{Zn})$, tin, and Ni. Applications of heavy metal compost may pollute the soil [37,38]. In addition, some studies have shown that the availability of heavy metals determines their bioavailability, mobility, or phytotoxicity in soil [39]. Therefore, it is important to discuss changes in the concentrations and morphology of heavy metals in compost to assess their bioavailability and mobility. According to the five-step continuous extraction method proposed by Tessier et al. [40], heavy metals can be divided into five binding states: the metal exchangeable state, the iron (manganese) oxide bound state, the carbonate 
state, the residue lattice bound state, and the organic and sulfide bound state. There are six kinds of $\mathrm{Cu}, \mathrm{Zn}$, $\mathrm{Cr}, \mathrm{Cd}, \mathrm{Pb}$, and $\mathrm{Ni}$ in municipal wastewater. In addition, most studies on heavy metals in wastewater are based on these six metals. To make the results more representative, we investigated these six heavy metals $(\mathrm{Cu}, \mathrm{Zn}, \mathrm{Cr}, \mathrm{Cd}, \mathrm{Pb}$, and $\mathrm{Ni})$.

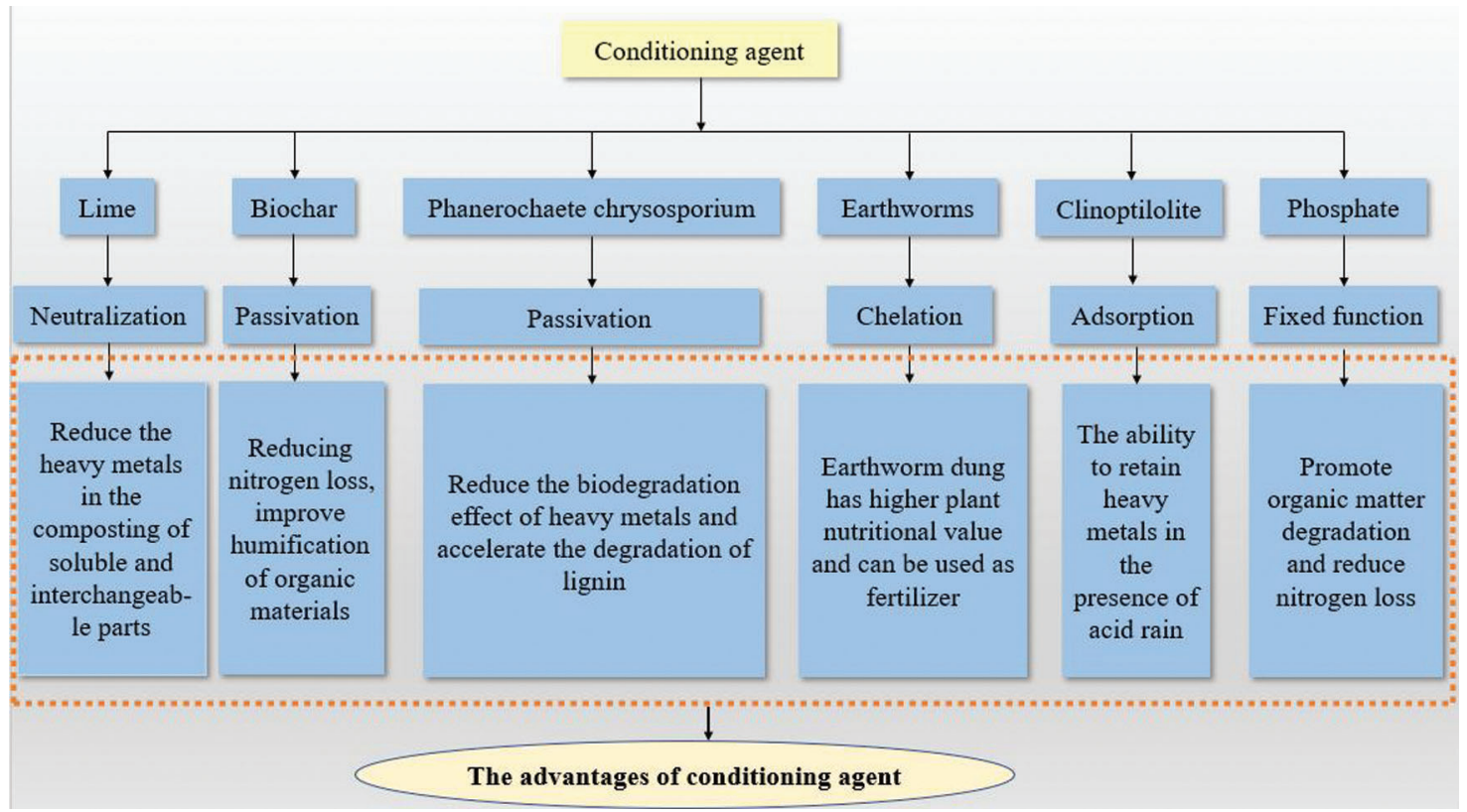

Figure 1: The action mechanism and outstanding advantages of different conditioning agents in the treatment of heavy metals in sludge composting

Tabs. 1 and 2 respectively summarize the specific effects of the absence of conditioning agents and adding different conditioning agents on specific forms or concentrations of heavy metals in compost.

Table 1: Changes of heavy metal speciation during composting without conditioning agent

\begin{tabular}{|c|c|c|c|c|}
\hline Treatment & Sludge source & $\begin{array}{l}\text { Heavy } \\
\text { metal }\end{array}$ & Changes of heavy metals & Ref. \\
\hline \multirow[t]{3}{*}{$\begin{array}{l}\text { The aerobically digested and } \\
\text { dewatered sludges }\end{array}$} & \multirow[t]{3}{*}{$\begin{array}{l}\text { The Min-Shen MSTP in } \\
\text { Northern Taiwan }\end{array}$} & $\mathrm{Cu}$ & $\begin{array}{l}\mathrm{Cu} \text { mainly exist in the Organic matter/sulfide-bound fraction in the } \\
\text { composting process }\end{array}$ & [41] \\
\hline & & $\mathrm{Zn}$ & $\begin{array}{l}\mathrm{Zn} \text { from stable components [Organic matter/sulfide-bound fraction } \\
\text { and Residual fraction] significantly shifted to flow components } \\
\text { [Exchangeable fraction and Carbonate bound fraction, Fe/Mn oxide- } \\
\text { bound fraction] }\end{array}$ & \\
\hline & & $\mathrm{Pb}$ & $\mathrm{Pb}$ increased from $26 \%$ to $36 \%$ in the mobile fractions after compost & \\
\hline \multirow[t]{2}{*}{$\begin{array}{l}\text { Dehydrated digested sewage } \\
\text { sludge }\end{array}$} & \multirow[t]{2}{*}{$\begin{array}{l}\text { Beixiaohe wastewater } \\
\text { treatment plant, Beijing }\end{array}$} & $\mathrm{Cr}$ & $\begin{array}{l}\text { Residue fractions of } \mathrm{Cr} \text { is mainly converted from carbonate binding, } \\
\text { Fe-Mn oxide binding and organic binding. The binding rate of } \mathrm{Cr} \\
\text { and oxidized parts decreased from } 32.8 \% \text { to } 25.9 \%\end{array}$ & [31] \\
\hline & & $\mathrm{Ni}$ & $\begin{array}{l}\text { Organic matter-bound } \mathrm{Ni} \text { was a major contributor to the residual } \\
\text { fraction. The binding rate of } \mathrm{Ni} \text { and oxidized parts decreased from } \\
60.7 \% \text { to } 42.9 \%\end{array}$ & \\
\hline
\end{tabular}




\begin{tabular}{|c|c|c|c|c|}
\hline Treatment & Sludge source & $\begin{array}{l}\text { Heavy } \\
\text { metal }\end{array}$ & Changes of heavy metals & Ref. \\
\hline \multirow{4}{*}{$\begin{array}{l}\text { Sewage sludge and compost } \\
\text { samples containing municipal } \\
\text { sludge }\end{array}$} & \multirow[t]{4}{*}{$\begin{array}{l}\text { Podlasie province } \\
\text { (Poland) }\end{array}$} & $\mathrm{Cu}$ & $\begin{array}{l}\mathrm{Cu} \text { was bound to organic matter, the } \mathrm{Cu} \text { content in dehydrated sludge } \\
\text { and mature compost is up to } 76.50 \% \text { and } 75.10 \% \text {, respectively }\end{array}$ & \multirow[t]{4}{*}[42]{} \\
\hline & & $\mathrm{Zn}$ & $\begin{array}{l}\text { The binding rate of } \mathrm{Zn} \text { with reducible fraction increased from } \\
42.80 \% \text { to } 59.10 \% \text { in compost }\end{array}$ & \\
\hline & & $\mathrm{Cr}$ & $\begin{array}{l}\text { The binding rate of } \mathrm{Cr} \text { and oxidized parts decreased from } 41.6 \% \text { to } \\
32.0 \%\end{array}$ & \\
\hline & & $\mathrm{Ni}$ & $\begin{array}{l}\text { The binding rate of } \mathrm{Ni} \text { and oxidized parts decreased from } 38.0 \% \text { to } \\
32.4 \%\end{array}$ & \\
\hline \multirow[t]{4}{*}{ Sewage sludge } & \multirow{4}{*}{$\begin{array}{l}\text { A sewage treatment plant } \\
\text { in Pomerania, northern } \\
\text { Poland }\end{array}$} & $\mathrm{Cu}$ & \multirow{4}{*}{$\begin{array}{l}\text { The compost was stable after maturation and the mobility of heavy } \\
\text { metals was reduced }\end{array}$} & \multirow[t]{4}{*}{ [43] } \\
\hline & & $\mathrm{Zn}$ & & \\
\hline & & $\mathrm{Cr}$ & & \\
\hline & & $\mathrm{Cd}$ & & \\
\hline \multirow[t]{5}{*}{ Sewage sludge } & \multirow{5}{*}{$\begin{array}{l}\text { Beixiaohe } \\
\text { Wastewater } \\
\text { treatment plant, Beijing }\end{array}$} & $\mathrm{Zn}$ & \multirow[t]{3}{*}{ The contents of residue fraction for $\mathrm{Zn}$ was decreased } & \multirow[t]{5}{*}{ [44] } \\
\hline & & $\mathrm{Cd}$ & & \\
\hline & & $\mathrm{Pb}$ & & \\
\hline & & $\mathrm{Cr}$ & \multirow[t]{2}{*}{ Increase } & \\
\hline & & $\mathrm{Ni}$ & & \\
\hline
\end{tabular}

Table 2: Changes of heavy metal speciation during composting with different conditioning agent

\begin{tabular}{|c|c|c|c|c|c|}
\hline Method name & Treatment & Sludge source & $\begin{array}{l}\text { Heavy } \\
\text { metal }\end{array}$ & Changes of heavy metals & Ref. \\
\hline \multirow{4}{*}{$\begin{array}{l}\text { Phosphate } \\
\text { amendments }\end{array}$} & \multirow{4}{*}{$\begin{array}{l}\text { Dewatered fresh sewage } \\
\text { sludge (DFSS) }\end{array}$} & \multirow{4}{*}{$\begin{array}{l}\text { A municipal } \\
\text { wastewater treatment } \\
\text { plant in Shanghai }\end{array}$} & $\mathrm{Cu}$ & Mobility was reduced by $18.8 \%$ & \multirow[t]{4}{*}[45]{} \\
\hline & & & $\mathrm{Zn}$ & Mobility was reduced by $1.7 \%$ & \\
\hline & & & $\mathrm{Cd}$ & Mobility was reduced by $24.2 \%$ & \\
\hline & & & $\mathrm{Pb}$ & $\begin{array}{l}\text { With maximum passivation capacity, mobility increased } \\
\text { by } 1.8 \%\end{array}$ & \\
\hline $\begin{array}{l}\text { Hydroxy- } \\
\text { apatite }\end{array}$ & Sewage sludge & $\begin{array}{l}\text { Qinhuangdao City, } \\
\text { China }\end{array}$ & $\mathrm{Cd}$ & $\begin{array}{l}\text { Adding } 1.5 \% \text { hydroxyapatite, the increment of } \\
\text { exchangeable Cd decreased by } 38.3 \% \text { and the increment } \\
\text { of residual } \mathrm{Cd} \text { increased by } 37.7 \%\end{array}$ & [46] \\
\hline \multirow{4}{*}{$\begin{array}{l}\text { Phanerochaete } \\
\text { chrysosporium }\end{array}$} & \multirow{4}{*}{$\begin{array}{l}\text { Sewage } \\
\text { sludge }\end{array}$} & \multirow[t]{4}{*}{ River sediment } & $\mathrm{Cu}$ & The decreased percentage of $\mathrm{Cu}$ is $25.29 \%$ & \multirow[t]{4}{*}[47]{} \\
\hline & & & $\mathrm{Zn}$ & The decreased percentage of $\mathrm{Zn}$ is $14.67 \%$ & \\
\hline & & & $\mathrm{Cd}$ & The decreased percentage of $\mathrm{Cd}$ is $31.08 \%$ & \\
\hline & & & $\mathrm{Pb}$ & The decreased percentage of $\mathrm{Pb}$ is $13.84 \%$ & \\
\hline \multirow[t]{4}{*}{ Clinoptilolite } & \multirow{4}{*}{$\begin{array}{l}\text { Dewatered anaerobically } \\
\text { stabilized primary sewage } \\
\text { sludge (DASPSS) }\end{array}$} & \multirow{4}{*}{$\begin{array}{l}\text { Psittalia's wastewater } \\
\text { treatment plant (Rock } \\
\text { Island in Saronic } \\
\text { Gulf in Athens, Greece) }\end{array}$} & $\mathrm{Cu}$ & $\begin{array}{l}\text { After maturation, } \mathrm{Cu} \text { is associated with residual and } \\
\text { organic components ( } 54 \% \text { and } 32 \% \text {, respectively) }\end{array}$ & \multirow[t]{4}{*}{48} \\
\hline & & & $\mathrm{Cr}$ & $\begin{array}{l}47.74 \% \text { and } 32.75 \% \text { of } \mathrm{Cr} \text { is associated with the organic } \\
\text { fraction and the residual fraction, respectively. All heavy } \\
\text { metals are reduced }\end{array}$ & \\
\hline & & & $\mathrm{Pb}$ & $\begin{array}{l}75 \% \text { of the } \mathrm{Pb} \text { was associated with the residual fraction } \\
\text { and } 15.58 \% \text { with the reducible fraction }\end{array}$ & \\
\hline & & & $\mathrm{Ni}$ & $\begin{array}{l}\text { Before composting, Ni was associated with reducible } \\
\text { content }(36 \%) \text { and residual content }(23 \%) \text {. At high } \\
\text { temperatures, } 52 \% \text { of } \mathrm{Ni} \text { is associated with residual } \\
\text { fraction }\end{array}$ & \\
\hline Lime & $\begin{array}{l}\text { Dewatered anaerobically } \\
\text { digested sewage sludge }\end{array}$ & $\begin{array}{l}\text { Tai Po sewage } \\
\text { treatment plant in } \\
\text { Hong Kong }\end{array}$ & $\mathrm{Cu}$ & $\begin{array}{l}\text { At the beginning of the compost, } \mathrm{Cu} \text { mainly exists in its } \\
\text { residual form, and after the compost, Cu mainly exists in } \\
\text { the oxidizable form. The content of all metals decreases } \\
\text { with the increase of lime correction rate }\end{array}$ & [49] \\
\hline
\end{tabular}


JRM, 2022, vol.10, no.2

Table 2 (continued).

\begin{tabular}{|c|c|c|c|c|c|}
\hline Method name & Treatment & Sludge source & $\begin{array}{l}\text { Heavy } \\
\text { metal }\end{array}$ & Changes of heavy metals & Ref. \\
\hline & & & $\mathrm{Zn}$ & $\begin{array}{l}\text { The residual } \mathrm{Zn} \text { in the composting process is mainly } \\
\text { converted into oxidizable } \mathrm{Zn}\end{array}$ & \\
\hline & & & $\mathrm{Pb}$ & After compost, $\mathrm{Pb}$ is mainly in residual form & \\
\hline & & & $\mathrm{Ni}$ & $\begin{array}{l}\text { At first, } \mathrm{Ni} \text { is mainly in reducible form, but after } \\
\text { composting, it is mainly in residual form }\end{array}$ & \\
\hline $\begin{array}{l}\text { Synthetic } \\
\text { zeolites }\end{array}$ & $\begin{array}{l}\text { Sewage } \\
\text { sludge }\end{array}$ & NA & $\mathrm{Zn}$ & $\begin{array}{l}\text { Adding } 0.5 \% \text { and } 1.0 \% \text { zeolite can significantly reduce } \\
\text { unstable } \mathrm{Zn} \text { within } 90 \text { days }\end{array}$ & {$[50]$} \\
\hline \multirow{5}{*}{$\begin{array}{l}\text { Natural zeolite } \\
\text { clinoptilolite }\end{array}$} & \multirow{5}{*}{$\begin{array}{l}\text { Dewatered and } \\
\text { anaerobically stabilized } \\
\text { primary sewage sludge } \\
\text { (DASPSS) }\end{array}$} & \multirow{5}{*}{$\begin{array}{l}\text { Psittalia wastewater } \\
\text { treatment plant in } \\
\text { Athens, Greece }\end{array}$} & $\mathrm{Cu}$ & $25 \% \mathrm{w} / \mathrm{w}$ of zeolite takes up to $27 \%$ of $\mathrm{Cu}$ & \multirow[t]{5}{*}[51]{} \\
\hline & & & $\mathrm{Zn}$ & $25 \% \mathrm{w} / \mathrm{w}$ of zeolite takes up to $40 \%$ of $\mathrm{Zn}$ & \\
\hline & & & $\mathrm{Cr}$ & $25 \% \mathrm{w} / \mathrm{w}$ of zeolite takes up to $14 \%$ of $\mathrm{Cr}$ & \\
\hline & & & $\mathrm{Pb}$ & $25 \% \mathrm{w} / \mathrm{w}$ of zeolite takes up to $55 \%$ of $\mathrm{Pb}$ & \\
\hline & & & $\mathrm{Ni}$ & $25 \% \mathrm{w} / \mathrm{w}$ of zeolite takes up to $60 \%$ of $\mathrm{Ni}$ & \\
\hline \multirow[t]{6}{*}{ Clinoptilolite } & \multirow{6}{*}{$\begin{array}{l}\text { Dewatered anaerobically } \\
\text { stabilized primary sewage } \\
\text { sludge (DASPSS) }\end{array}$} & \multirow{6}{*}{$\begin{array}{l}\text { The Psittalia } \\
\text { wastewater treatment } \\
\text { plant in Athens }\end{array}$} & $\mathrm{Cu}$ & $25 \%-30 \%$ clinoptilolite take up to $28 \%-45 \%$ of $\mathrm{Cu}$ & \multirow[t]{6}{*}[52]{} \\
\hline & & & $\mathrm{Zn}$ & $25 \%-30 \%$ clinoptilolite take up to $40 \%-46 \%$ of $\mathrm{Zn}$ & \\
\hline & & & $\mathrm{Cr}$ & $25 \%-30 \%$ clinoptilolite take up to $10 \%-15 \%$ of $\mathrm{Cr}$ & \\
\hline & & & $\mathrm{Cd}$ & $25 \%-30 \%$ clinoptilolite take up to $100 \%$ of $\mathrm{Cd}$. & \\
\hline & & & $\mathrm{Pb}$ & $25 \%-30 \%$ clinoptilolite take up to $50 \%-55 \%$ of $\mathrm{Pb}$. & \\
\hline & & & $\mathrm{Ni}$ & $25 \%-30 \%$ clinoptilolite take up to $50 \%-55 \%$ of $\mathrm{Ni}$ & \\
\hline \multirow[t]{6}{*}{ Biochar } & \multirow{6}{*}{$\begin{array}{l}\text { The dewatered fresh } \\
\text { sewage sludge }\end{array}$} & \multirow{6}{*}{$\begin{array}{l}\text { An urban sewage } \\
\text { treatment plant in } \\
\text { Tianjin, China }\end{array}$} & $\mathrm{Cu}$ & The content of effective $\mathrm{Cu}$ decreased & \multirow[t]{6}{*}[53]{} \\
\hline & & & $\mathrm{Zn}$ & The content of effective $\mathrm{Zn}$ increased & \\
\hline & & & $\mathrm{Cr}$ & The content of effective $\mathrm{Cr}$ decreased & \\
\hline & & & $\mathrm{Cd}$ & The content of effective $\mathrm{Cd}$ increased & \\
\hline & & & $\mathrm{Pb}$ & The content of effective $\mathrm{Pb}$ decreased the most & \\
\hline & & & $\mathrm{Ni}$ & The content of effective Ni decreased & \\
\hline \multirow{4}{*}{$\begin{array}{l}\text { Modified } \\
\text { biochar }\end{array}$} & \multirow{4}{*}{$\begin{array}{l}\text { Dewatered fresh sewage } \\
\text { sludge (DFSS) }\end{array}$} & \multirow{4}{*}{$\begin{array}{l}\text { The wastewater } \\
\text { treatment plant at } \\
\text { Yangling, Shaanxi }\end{array}$} & $\mathrm{Cu}$ & It increases slightly in the biological oxidation stage and & \multirow[t]{4}{*}{ [54] } \\
\hline & & & $\mathrm{Zn}$ & then decreases gradually & \\
\hline & & & $\mathrm{Pb}$ & It starts to increase throughout maturity and then & \\
\hline & & & $\mathrm{Ni}$ & gradually decreases & \\
\hline \multirow{3}{*}{$\begin{array}{l}\text { Sodium sulfide } \\
\text { and lime } \\
\text { (SSL) }\end{array}$} & \multirow[t]{3}{*}{$\begin{array}{l}\text { Dewatered aerobic sewage } \\
\text { sludge }\end{array}$} & \multirow{3}{*}{$\begin{array}{l}\text { The Quyang sewage } \\
\text { treatment plant in } \\
\text { Shanghai }\end{array}$} & $\mathrm{Cu}$ & $\begin{array}{l}\text { Organic matter and sulfide combined with } \mathrm{Cu} \text { are mainly } \\
\text { converted into residual parts }\end{array}$ & \multirow[t]{3}{*}[55]{} \\
\hline & & & $\mathrm{Zn}$ & $\begin{array}{l}\text { After composting, the } \mathrm{Zn} \text { residual part dominated the } \\
\text { compost }\end{array}$ & \\
\hline & & & $\mathrm{Ni}$ & $\begin{array}{l}\text { Carbonate binding state, iron and manganese oxide } \\
\text { binding state, organic matter and } \mathrm{Ni} \text { sulfide are mainly } \\
\text { converted into residual forms of } \mathrm{Ni}\end{array}$ & \\
\hline \multirow[t]{5}{*}{ Earthworms } & \multirow[t]{5}{*}{ Dewatered sludge } & \multirow[t]{5}{*}{ NA } & $\mathrm{Cu}$ & \multirow{5}{*}{$\begin{array}{l}\text { The concentration of heavy metals decreased after } \\
\text { earthworms absorbed heavy metals and removed } \\
\text { earthworms from compost }\end{array}$} & \multirow[t]{5}{*}{ [56] } \\
\hline & & & $\mathrm{Zn}$ & & \\
\hline & & & $\mathrm{Cd}$ & & \\
\hline & & & $\mathrm{Pb}$ & & \\
\hline & & & $\mathrm{Ni}$ & & \\
\hline \multirow[t]{5}{*}{ Earthworms } & \multirow{5}{*}{$\begin{array}{l}\text { Final SS produced by } \\
\text { activated sludge process }\end{array}$} & Sewage treatment plant & $\mathrm{Cu}$ & The concentration of heavy metals decreased & {$[57]$} \\
\hline & & in Kuala Lumpur & $\mathrm{Zn}$ & & \\
\hline & & & $\mathrm{Cr}$ & & \\
\hline & & & $\mathrm{Cd}$ & & \\
\hline & & & $\mathrm{Pb}$ & & \\
\hline
\end{tabular}


By analyzing Tabs. 1, 2 and their corresponding references, it can be found that the compost was stable after maturation and the mobility of heavy metals was reduced. the addition of Phanerochaete chrysosporium can effectively reduce the concentrations of $\mathrm{Cu}, \mathrm{Zn}, \mathrm{Cd}$ and $\mathrm{Pb}$. adding biochar can decrease the active concentration of $\mathrm{Cu}, \mathrm{Cr}, \mathrm{Pb}$ and $\mathrm{Ni}$. the concentration of heavy metals decreased after earthworms absorbed heavy metals and removed earthworms from compost. The specific removal of each metal is described in detail in the following article.

\subsection{Copper $(\mathrm{Cu})$}

Soil $\mathrm{Cu}$ content far exceeds the carrying capacity of the soil environment with the mining of $\mathrm{Cu}$, discharge of waste from smelters, the long-term and large use of $\mathrm{Cu}$-containing fungicides, and the composting of municipal sludge. Global $\mathrm{Cu}$ content typically ranges from 2 to $100 \mathrm{mg} / \mathrm{kg}$. Different soils have different $\mathrm{Cu}$ capacities, and different regions have different effects. There is no specific value. High $\mathrm{Cu}$ content is harmful to animals, plants, and soil microorganisms. Damage to the cytoplasmic membrane of the root system hinders root elongation, lateral roots become shorter, new leaves lose their green color, and old leaves to die. In animals, organ damage and metabolic disturbances lead to physical discomfort. $\mathrm{Cu}$ controls the growth of microorganisms, resulting in changes in quantity and population structure and seriously threatens stability of the ecosystem and human security. Therefore, soil $\mathrm{Cu}$ pollution is an urgent problem $[58,59]$.

Nomeda et al. [41] found that after dealing with the composting, $\mathrm{Cu}$ stability of sludge and compost mixture components (sulfide/organic matter-bound fraction and residual fraction) have great affinity. The potential mobility and bioavailability of $\mathrm{Cu}$ decreases after composting. Ignatowicz used the BCR (European Communities Bureau of Reference) method to determine content. Organics account for $76.50 \%$ of total $\mathrm{Cu}$ content, which is conducive to the formation of strong metal-organic complexes and greatly reduces $\mathrm{Cu}$ mobility [42]. In addition, the results of Bożym et al. [43] are consistent with the above that the mobility of $\mathrm{Cu}$ decreases when no conditioning agent is added to compost.

In contrast, zeolite has a pore-forming silica lattice, with uniform pore size and large holes on the inner surface of the crystal allowing for strong adsorption of heavy metal ions. About $25 \%-30 \%$ clinoptilolite is used during the composting process, and $28 \%-45 \%$ of the $\mathrm{Cu}$ is absorbed by zeolite [52]. This result is similar to that of Zorpas et al. [48] $\mathrm{Cu}$ is mainly related to residual and organic components when the compost matures. Zorpas et al. [51] reported that the particle size of clinoptilolite affects its adsorption of heavy metals, and the metal content of the clinoptilolite increases with increased particle size. Using zeolite (particle size 3.3-4.0 $\mathrm{mm}$ ) effectively removes $27 \%$ of the $\mathrm{Cu}$.

When Wong et al. [49] added lime to sludge, the $\mathrm{Cu}$ form was significantly different before and after composting, and the oxidizable part (organic binding) increased significantly, but it was still mainly in the oxidation state. By Wang et al. [55] reported that $\mathrm{Cu}$ in the combined state of organic matter and sulfide is mainly converted to the residual state after mixing sodium sulfide with lime (SSL) during composting, but it mainly exists in the organic matter and sulfide components.

Some authors have found that adding $6 \%$ biochar has the best passivation effect on $\mathrm{Cu}$, and that $\mathrm{Cu}$ content decreases significantly after composting [53]. However, Awasthi et al. [54] reported that limemodified biochar reduces the bioavailability of $\mathrm{Cu}$ by $34.81 \%$, and the passivation effect was better than that of lime alone. Liu et al. [56] found that earthworms accumulate heavy metals from sludge during composting; the concentration of heavy metals in earthworm compost decreases, but the concentration of heavy metals in earthworm dung increases. This is the same conclusion reached by Bakar et al. [57].

In addition, Wang et al. [45] used phosphate modifiers during sludge composting, and the results showed that the mobility of $\mathrm{Cu}$ decreases by $18.8 \%$ after adding calcium magnesium phosphate. Chen et al. [47] 
inoculated composting river sediments with Phanerochaete chrysosporium and reported that it was beneficial for passivation of $\mathrm{Cu}$, and the percentage of $\mathrm{Cu}$ decreased by $25.29 \%$.

\subsection{Zinc (Zn)}

The main sources of $\mathrm{Zn}$ pollution include $\mathrm{Zn}$ mining, smelting, machinery manufacturing, Zn plating, instrumentation, organic synthesis, papermaking, and other industrial emissions, automobile tire wear and coal burning dust, soot containing $\mathrm{Zn}$ and compounds, and $\mathrm{Zn}$ in industrial wastewater with a $\mathrm{Zn}$ hydroxyl complex. Moreover, the scope of $\mathrm{Zn}$ pollution is wide, as $\mathrm{Zn}$ pollutes the air, water, and soil. However, soil pollution is different from air pollution. Once formed, harmful substances that accumulate in the soil migrate into the water, air, and plants, and eventually enter the human body, causing long-term effects. Therefore, we must reduce heavy metal content in compost to reach a standard value before applying sludge compost.

In Nomeda et al. [41] study, stable components (organic matter/sulfide-bound fraction and residual fraction) of $\mathrm{Zn}$ into flow components (exchangeable fraction, carbonate-bound fraction, and Fe/Mn oxidebound fraction), the total $\mathrm{Zn}$ content increased. Moreover, the potential mobility and bioavailability of $\mathrm{Zn}$ improve significantly. Similarly, Ignatowicz [42] reported that the binding rate of $\mathrm{Zn}$ with the reducible fraction increases from $42.80 \%$ to $59.10 \%$ in compost. This result was confirmed by Bożym et al. [43]. The total fluidity of $\mathrm{Zn}$ components (exchangeable fraction, carbonate bound fraction, and reducible iron) increase significantly when no conditioning agent is added to the compost [44].

In addition, Zorpas et al. [51] reported that $25 \%$ (w/w) zeolite adsorbs $40 \%$ of the $\mathrm{Zn}$. Zorpas et al. also studied the adsorption of heavy metals by zeolite during the early stage. A mixture of $25 \%-30 \%$ clinoptilolite adsorbs $40 \%-46 \%$ of the $\mathrm{Zn}$ [52]. Some scholars have shown that adding $0.5 \%$ and $1.0 \%$ synthetic zeolite significantly reduces unstable $\mathrm{Zn}$ during composting [50].

Wong et al. [49] used lime and sludge co-composting and found that adding lime reduces the conversion of residual $\mathrm{Zn}$ to oxidized $\mathrm{Zn}$ and reduces the availability of $\mathrm{Zn}$. However, Wang et al. [55] found that SSL mixed with sludge compost significantly reduces the dynamics and accessibility in the compost (exchange state and carbonate combined with recent). The $\mathrm{Zn}$ residual part dominated after composting.

Awasthi et al. [54] reported that adding lime-modified biochar to sludge compost reduces the bioavailability of $\mathrm{Zn}$ by $56.74 \%$. However, other studies have reported different results. Liu et al. [53] used biochar as a conditioning agent and found that effective $\mathrm{Zn}$ content increases after composting. Some scholars have used earthworm composting to reduce heavy metals during sludge composting through biological accumulation [56,57].

In particular, Wang et al. added phosphate modifiers to compost and the mobility of $\mathrm{Zn}$ was reduced by $1.7 \%$ [45]. Some studies inoculated $P$. chrysosporium in river sediment compost, but found no effect on $\mathrm{Zn}$ [47].

\subsection{Cadmium (Cd)}

$\mathrm{Cd}$ is one of the most toxic elements in the food chain, and is a limiting factor in the land use of sludge. $\mathrm{Cd}$ is a common mobile metal in sludge. It is not a necessary trace element in the natural environment, and is very harmful. Bożym et al. reported that high Cd concentrations reduce or completely inhibit the activities of microorganisms under aerobic or anaerobic conditions. Cd often pollutes soil; however, the mobility of Cd is greatly reduced after composting [43]. Researchers have performed a series of studies on the migration and transformation of Cd. Wang et al. [45] discovered that adding calcium magnesium phosphate to composting sludge reduces the mobility of $\mathrm{Cd}$ by $24.2 \%$. At the same time, Yuan et al. [60] reported that ferrous sulfate and phosphate have a synergistic effect on reducing the mobility of heavy metals in soil.

The soluble and exchangeable heavy metals are effective in plants, while the residual heavy metals belong to the ineffective part. Under certain conditions, other forms may be released slowly and in small 
amounts to supplement the effective state. The uptake of Cd by plants does not depend on the total amount of $\mathrm{Cd}$ in soil, but on the availability and existing forms of $\mathrm{Cd}$. Therefore, experts have used a variety of conditioning agents to observe the results of various morphological changes. Hydroxyapatite (HAP) is a good modifier. HAP improves the environment by reducing the absorption of $\mathrm{Cd}$ by turfgrass. Liu et al. [46] added HAP to sludge in a composting experiment and found that it significantly improves greenness, the green retention period, and root strength of turfgrass in modified soil. Adding $1.5 \%$ HAP (1.5\% is the most economical) to sludge compost reduces exchangeable $\mathrm{Cd}$ content by $6.0 \%$ and increases residual $\mathrm{Cd}$ content by $7.6 \%$. Compared with single sludge compost, the increase in exchangeable Cd decreased by $38.3 \%$ and the reduction rate of residual $\mathrm{Cd}$ increased by $37.7 \%$ after adding $1.5 \% \mathrm{HAP}$, indicating that HAP has an effect on $\mathrm{Cd}$. Liu et al. [44] reported that Cd residue content decreases during composting. Zorpas et al. [48] determined that clinoptilolite removes cations from aqueous solution and the solid phase, particularly heavy metals, such as $\mathrm{Cr}$ with increasing dosage, and it absorb $100 \%$ of the $\mathrm{Cd}$ to reduce its content. Chromium is transformed from a reducible and organic component into a residual component.

The activity and bioavailability of $\mathrm{Cd}$ in sludge compost is high. Chen et al. [47] reported that the passivation effect of $P$. chrysosporium on $\mathrm{Cd}$ is enhanced. The bioavailability of $\mathrm{Cd}$ decreases by $28.25 \%$ during composting. Yellow rot fungus accelerates the composting process and the degree of humification

and promotes the maturation of agricultural waste and river sediment. Adding this material to the composting process reduces $\mathrm{Cd}$ by $31.08 \%$.

\section{$2.4 \operatorname{Lead}(\mathrm{Pb})$}

$\mathrm{Pb}$ is a relatively stable metal that usually exists as a bivalent insoluble compound in the soil environment, and water-soluble $\mathrm{Pb}$ content is very low. $\mathrm{Pb}$ is a nonessential element in plants. It affects seed germination when absorbed by plants and is toxic to the human body. However, sludge composting effectively reduces $\mathrm{Pb}$ content. Liu et al. [44] showed that the contents of residual $\mathrm{Pb}$ and $\mathrm{Cd}$ components decrease and the contents of total mobile components of $\mathrm{Zn}$ and $\mathrm{Pb}$ increase significantly during composting. The heavy metals $\mathrm{Zn}, \mathrm{Cu}, \mathrm{Ni}, \mathrm{Pb}, \mathrm{Cd}$, and $\mathrm{Cr}$ are enriched during this complex process.

The biological availability of $\mathrm{Pb}$ is related to organic matter, the structure and cation exchange capacity of the soil, and to the form and distribution of $\mathrm{Pb}$ in the soil. Nomeda et al. investigated the distribution of $\mathrm{Pb}$ during sludge composting using sludge from Taiwan $(\mathrm{Pb}: 1,200 \mathrm{mg} / \mathrm{kg}$ ), whose concentration is far lower than that of the European Union sludge directive. $\mathrm{Pb}$ is closely related to stable components (organic matter/sulfide component and residual component). The mobility and bioavailability of $\mathrm{Pb}$ increases during composting. The effect of the granular metal form on the environment is closely related to migratory behavior during sludge composting. The $\mathrm{Pb}$ content in the remaining part of the sludge is higher, reaching $70 \%$. More than $93 \%$ of the $\mathrm{Cu}$ is distributed in the stable components of sewage sludge and recycled compost, while the $\mathrm{Cu}$ content in sawdust is only $56 \%$. The distribution of $\mathrm{Pb}$ is similar to that of $\mathrm{Cu}$. Moreover, the fluidity of $\mathrm{Pb}$ in raw materials is high. $\mathrm{Pb}$ mainly exists in a residual state in sewage sludge, from $32 \%$ to $17 \%$. The transformation of $\mathrm{Pb}$ to more mobile (bioavailable) components occurs during the last stage of composting, so the proportion of $\mathrm{Pb}$ in stable components is higher. This finding indicates that heavy metals, such as $\mathrm{Pb}$, are not easily released from these sludge and compost mixtures [41].

Wong et al. [49] studied the redistribution of $\mathrm{Pb}$ in lime compost sludge using a metal speciation analysis. A total of $54 \%-60 \%$ of the $\mathrm{Pb}$ existed in its residual form, and the residual form of $\mathrm{Pb}$ increased after lime was added. The exchangeable components are almost nonexistent by the end of composting.

$\mathrm{Pb}$ forms a stable complex with humus in sludge soil, and the $\mathrm{Pb}$ concentration in soil is positively correlated with humus content. The mobility and availability of $\mathrm{Pb}$ in soil depend on $\mathrm{pH}$, eh, organic matter content, texture, available phosphorus, and amorphous iron manganese oxides. However, adding 
conditioning agents also has an effect on the migration and transformation of $\mathrm{Pb}$, such as adding phosphate. Phosphate reduces activation of $\mathrm{Pb}$, and the toxicity of phosphate in compost does not increase, and it even promotes plant growth. Adding phosphate ensures an increase in the temperature and degradation of organic matter during sludge composting. Wang et al. [45] showed that the mobility of $\mathrm{Pb}$ in sludge compost samples containing various phosphate modifiers increases, but that samples treated with potassium phosphate showed the largest $\mathrm{Pb}$ passivation ability and the lowest increase in mobility $(1.8 \%)$. Clinoptilolite absorbs most exchangeable and carbonizable metals [52]. Zorpas et al. reported that zeolite adsorbs a large amount of heavy metals, as $25 \%(\mathrm{w} / \mathrm{w})$ zeolite accounts for $55 \%$ of the $\mathrm{Pb}$. The amount of metal absorbed by clinoptilolite increases as the particle size of the diabase increases. Therefore, the use of small particles achieves a high rate ion exchange process [51].

Biochar and microorganisms are increasingly being used during sludge composting. Liu et al. [53] confirmed that adding biochar and microbes reduces the effectiveness of $\mathrm{Pb}$; thus, improving maturity of the final product. Awasthi et al. [54] found that adding lime-modified biochar reduces the bioavailability of $\mathrm{Pb}$ by $87.96 \%$ and improves the maturity of the compost. Liu et al. [56] studied bioaccumulation factors and reported that earthworm composting effectively removes heavy metals, and the total content of five metals $(\mathrm{Cu}, \mathrm{Ni}, \mathrm{Cd}, \mathrm{Pb}$, and $\mathrm{Zn})$ was reduced. Bakar et al. also demonstrated this finding. They found that the concentrations of heavy metals in earthworm manure are higher than the initial concentrations because the heavy metals in earthworm manure combined with the heavy metals in earthworm manure, reduces the accumulation of heavy metals in earthworm tissues [57].

\subsection{Chromium (Cr)}

$\mathrm{Cr}$ is widely found in the earth's crust. Cr minerals naturally occur in the form of oxides, hydroxides, sulfides, and silicates. Trace $\mathrm{Cr}$ promotes the production of some crops (such as wheat, peas, and cucumber), but a high concentration of $\mathrm{Cr}$ produces serious toxic effects on plants, and symptoms, such as dwarfism, leaf coil, and root brown, as well as short and stunted plants. Cr (III) is necessary for humans and is easily absorbed and accumulates in the human body, but it can be toxic. Cr enters the food chain through the soil-plant system and threatens human health.

The form of a heavy metal plays a very important role in its toxicity. Zheng et al. [31] measured heavy metal forms using the Tessier sequential extraction method: the $\mathrm{Cr}$ concentration in sludge increases steadily by $36.0 \%$ after aerobic composting, compared to the initial state. Chromium is exchangeable, and the carbonate binding state, Fe-Mn oxide binding state, and organic binding state of $\mathrm{Cr}$ increase. The stability of $\mathrm{Cr}$ in sludge improves. The $\mathrm{Cr}$ residue increases after the five Tessier extraction steps. The form of $\mathrm{Cr}$ is not only related to the total content of heavy metals, but also to $\mathrm{pH}$ and temperature. The correlation between $\mathrm{Cr}$ and composting temperature was 0.680 , and the correlation between the total flow component and composting temperature was 0.682 . The $\mathrm{pH}$ value of the $\mathrm{Cr}$ form has little relationship to the composting process [44].

Zorpas et al. [48] reported that total heavy metal contents increase, as the contents of $\mathrm{Cd}, \mathrm{Ni}, \mathrm{Mn}, \mathrm{Pb}$, and $\mathrm{Zn}$ increase and $\mathrm{Cu}$ and $\mathrm{Fe}$ contents decrease during dewatering and anaerobic stabilization of primary sewage sludge. The content of organic $\mathrm{Cr}$ is high during the high temperature composting stage.

Clinoptilolite effectively adsorbs heavy metals. Zorpas et al. [52] conducted a composting experiment with compost containing $25 \%-30 \%$ clinoptilolite, and the clinoptilolite absorbed $10 \%-15 \%$ of the $\mathrm{Cr}$. Zeolite $25 \%(\mathrm{w} / \mathrm{w})$ with a particle size of $3.3 \mathrm{~mm} / 4.0 \mathrm{~mm}$ removes $14 \%$ of the $\mathrm{Cr}$ [51]. the total amount of Heavy Metals in end products more than agriculture, urban sewage sludge composting and limit of organic fertilizer. 


\subsection{Nickel (Ni)}

Nickel is often dissolved in water in the form of halides, nitrates, sulfates, and some inorganic and organic complexes. Excessive consumption ( $250 \mathrm{mg}$ of soluble Ni per day) of Ni leads to poisoning. The $\mathrm{Ni}$ in the environment is the most important source of Ni. Preventing Ni from entering the environment is a human health concern.

The Ni concentration in sludge increased by $30.4 \%$ after the aerobic composting experiment performed by Zheng et al. [31] Ni changes from an exchangeable state to a carbonate state, a Fe-Mn oxidation state, or an organic state to reduce toxicity in sludge. Liu et al. [44] in the process of aerobic sludge compost, the residues of Ni increased, Ni flow component concentration increase was not obvious, almost no change, and the components from the selected parameters such as $\mathrm{pH}$, organic matter content of the compost temperature, a linear correlation. As $\mathrm{pH}$ decreased, $\mathrm{Ni}$ and total flow fraction increased. The correlation between the increase in $\mathrm{Ni}$ and the decrease in the $\mathrm{pH}$ value was 0.612 , and the correlation between the increase in the total flow fraction and the decrease in the $\mathrm{pH}$ value was 0.661 .

Ignatowicz used the BCR method to measure heavy metal content and the formation of heavy metalorganic complexes, and the binding degree was very high. Most heavy metals have a binding degree of $30 \%-40 \%$, so mobility of the heavy metals is greatly reduced. The three stages of chemical analysis of the extract revealed high $\mathrm{Ni}$ content, which stabilized at $35.30 \%$ of the total content in water sludge after mixing with wood chips. The Ni content in treated compost should not exceed the limit of biological utilization [42].

Zorpas et al. [48] reported that binding and exchangeable carbonate capacity was significant after adding clinoptilolite to compost, and $\mathrm{Ni}$ in the carbonate state is formed during the process. Zorpas et al. [52] used the continuous extraction method to determine that $70 \%$ of the Ni content was bound, particularly in the residue and organic components. About $50 \%-55 \%$ of the $\mathrm{Ni}$ content is absorbed by $25 \%-30 \%$ clinoptilolite compost. The effect of zeolite on heavy metals is mainly reflected in adsorption. According to Zorpas et al. [51], the proportions of heavy metals in zeolite with a particle size of $3.3 \mathrm{~mm} / 4.0 \mathrm{~mm}$ and $25 \%(\mathrm{w} / \mathrm{w})$ are $\mathrm{Cu}, 27 \%, \mathrm{Cr}, 14 \%, \mathrm{Zn}, 55 \%$, and $\mathrm{Ni}, 60 \%$. The metals adsorbed by the clinoptilolite increase with the increase in particle size of the clinoptilolite, and the adsorption of heavy metals by the $25 \%(\mathrm{w} / \mathrm{w})$ zeolite with a particle size of $3.3 \mathrm{~mm} / 4.0 \mathrm{~mm}$ is effective for composting treatment.

Wong et al. [49] found that composting and a $1.63 \%$ lime treatment changes the $\mathrm{pH}$ of sludge from neutral to alkaline during the maturation period; the $\mathrm{pH}$ eventually returns to near neutral, with a decrease in exchangeable $\mathrm{Ni}$ and mobility and an increase in the residual state. The content of extractable heavy metals in sludge products is lowered to reach the agriculture standard, compared to a single sludge compost. Lime processes Ni content in 21 days [54].

Wang et al. [55] reported that a mixture of SSL accelerates the process of Ni conversion from an effective state to a poorly effective state, with a decrease in the carbonate state, the content of organic state and vulcanized state increase, and the increase of Ni residual fraction, which greatly reduced the bioavailability of $\mathrm{Ni}$.

In summary, the removal mechanism and quantitative relationship between different metals can be explained by different methods. The clinoptilolite molecular sieve has the characteristics of ion exchange, adsorption separation, catalysis, and stability. Clinoptilolite removes $\mathrm{Cd}, \mathrm{Cu}, \mathrm{Zn}, \mathrm{Ni}, \mathrm{Pb}$, and $\mathrm{Cr}$ by ionexchange adsorption. Among them, ion exchange has a significant effect on the formation of the carbonate state, and clinoptilolite reduces the bioavailability of all heavy metals through adsorption.

Lime reduces the formation of metallic organics during composting of lime sludge by neutralizing the organic acids released, and converts some of the organic $\mathrm{Cd}$, organic $\mathrm{Cu}$, organic $\mathrm{Zn}$, organic $\mathrm{Ni}$, organic $\mathrm{Pb}$, and organic $\mathrm{Cr}$ into residues and reduces the fluidity of all heavy metals. 
Lime-modified biochar compost is superior to lime compost. Biochar itself contains many properties that are conducive to the passivation of heavy metals and this type of compost inhibits their activation. The content of surface oxygen-containing functional groups is beneficial to the passivation of heavy metals. Lime-modified biochar compost has high concentrations of humic and fulvic acids, which effectively reduce heavy metal contents. Adding biochar and microbial modifiers reduces the effectiveness of $\mathrm{Cu}$, $\mathrm{Cd}, \mathrm{Ni}, \mathrm{Zn}, \mathrm{Cr}$, and $\mathrm{Pb}$.

In addition, earthworm composting removes heavy metals from the compost through bioaccumulation. The main mechanism of the resistance to heavy metal pollution by earthworms is as follows: the lipid antioxidase system reduces oxidative stress, detoxifies chelated metals, activates lysosomes and the cytoplasm, and inhibits heavy metal activity. Thus, the concentrations of $\mathrm{Cu}, \mathrm{Zn}, \mathrm{Cd}, \mathrm{Pb}, \mathrm{Ni}$, and $\mathrm{Cr}$ decrease.

Phosphate transfers heavy metals from the bioavailable stage to the stable stage. Phosphate treatment reduces the fluidity of $\mathrm{Cd}, \mathrm{Cu}, \mathrm{Zn}$, and other heavy metals in compost. Adding phosphate greatly improves the fixation effect of heavy metals while reducing their activation. The mobility of a series of heavy metals represented by $\mathrm{Cu}$ and $\mathrm{Zn}$ decreases after adding phosphate modifiers, which may be due to the formation of $\mathrm{CuFeS}_{2}$ and $\mathrm{Zn} \mathrm{Cu}\left(\mathrm{P}_{2} \mathrm{O}_{7}\right)$ crystals during composting.

Finally, $P$. chrysosporium inactivates heavy metals by chelating organic humus. Through the passivation treatment of a series of heavy metals represented by these six heavy metals, the heavy metals can be reduced by adding $P$. chrysosporium during composting.

\subsection{Conditioning Agents to Treat Heavy Metals}

Based on the detailed interpretation of each metal, the main methods to remove heavy metals from sludge are discussed in detail. Then, the characteristics of the heavy metals in sludge compost are briefly described. The characteristics of these heavy metals are a major factor affecting removal efficiency.

$\mathrm{Pb}^{2+}$ is the most common and active form of the two valence states of $\mathrm{Pb}$, including the zero state and the divalent state. $\mathrm{Pb}^{2+}$ easily combines with inorganic ions, humic acids, or amino acids to form poorly soluble compounds.

Chromium (VI) is the most toxic and fluid material in sludge compost and is found mainly in the form of chromate and dichromate. $\mathrm{Cr}$ (VI) is reduced to $\mathrm{Cr}$ (III) with weak toxicity and mobility in the environment by organic matter, $\mathrm{S}^{2-}$, and $\mathrm{Fe}^{2-}$. The leaching concentration of $\mathrm{Cr}(\mathrm{VI})$ increases with $\mathrm{pH}$.

Environmental $\mathrm{pH}$ has a strong effect on $\mathrm{Cd}$ activity, and the $\mathrm{Cd}^{2+}$ activity is higher in soil under acidic conditions ( $\mathrm{pH} 4.5-5.5)$. Under a high soil $\mathrm{pH}, \mathrm{Cd}^{2+}$ precipitates with hydroxide and carbonate ions. $\mathrm{Cd}^{2+}$ also forms a precipitate with phosphate, dichromate, and $\mathrm{S}$ ions.

$\mathrm{Cu}$ has three valence states, such as $0,+1$, and +2 , with the strongest toxicity in the bivalent state. $\mathrm{Cu}^{2+}$ activity is highly dependent on $\mathrm{pH}$, which decreases with the increase in soil $\mathrm{pH} . \mathrm{Cu}^{2+}$ activity is regulated by the adsorption of carbonate, phosphate, and clay minerals.

In the environment, $\mathrm{Zn}^{2+}$ combines with hydroxides, carbonates, sulfates, phosphates, and other anions to form precipitates, and also combines with organic acids to form complexes. Under reducing conditions, $\mathrm{Zn}$ and $\mathrm{Fe} / \mathrm{Mn}$ and other hydrated oxides form co-precipitates.

The characteristics of these heavy metals are a major factor affecting removal efficiency. For example, biochar can be added to sludge compost to affect removal efficiency. Biochar for passivation of heavy metals in sludge, the removal of heavy metals in the compost similarities: biochar of nitrogen and phosphorus, potassium, calcium, magnesium, such as inorganic nutrients can be extracted, they are all with increase of $\mathrm{pH}$ value method to suppress the activation of heavy metals. The efficiency of removing heavy metals is affected by the sensitivity of each metal to $\mathrm{pH}$, and oxygen-containing functional groups on the surface favor passivation of heavy metals. 
And specific involves the change of each heavy metal quantity how much and is not the same, Principal component analysis (PCA) was used to analyze the effectiveness of heavy metals before and after composting. The contribution rates of principal component PC1-PC3 were $47.01 \%, 24.75 \%$, and 20.57\%, respectively. PC1 was the main factor affecting the availability of heavy metals in biochar compost. To further analyze the contribution of heavy metals to the three PCs, a factor loading analysis was performed on the three PCs. Pb had the largest contribution to PC1, Cr had the largest contribution to PC2, and As had the largest contribution to PC3. These results show that the different treatments have different passivation effects on the heavy metals, among which the $\mathrm{Pb}$ passivation effect was the best, followed by As and Cr.

Natural clinoptilolite, such as oblique zeolite, absorb and remove metals by ion exchange. Clinoptilolite uses ion exchange to remove cations from the aqueous solution and solid phases, which is how clinoptilolite removes heavy metals from water or sludge.

The removal effect of different heavy metals by clinoptilolite, such as $\mathrm{Zn}^{2+}, \mathrm{Pb}^{2+}, \mathrm{Cd}^{2+}$ and $\mathrm{Ni}^{2+}$ is also different. The selectivity of $\mathrm{Pb}, \mathrm{Cu}, \mathrm{Cd}, \mathrm{Zn}$, and $\mathrm{Cr}$ is higher than that of Ni. Thus, the clinoptilolite selective sequence is $\mathrm{Pb}>\mathrm{Cu}>\mathrm{Cd}>\mathrm{Zn}>\mathrm{Cr}>\mathrm{Ni}$. Clinoptilolite easily absorbs almost all metals bound to the exchangeable and carbonate components. Under these conditions, clinoptilolite occupies all metals in the exchangeable and carbonate components in the order of $\mathrm{Cu}>\mathrm{Cr}>\mathrm{Ni}>\mathrm{Pb}>\mathrm{Zn}$.

The metal content in clinoptilolite increases with an increase in particle size. Surface dust blocks some of the pores in the clinoptilolite structure, resulting in slower ion exchange kinetics for smaller particles than for larger particles during $\mathrm{Pb}^{2+} / \mathrm{Na}^{+}$ion exchange in water systems. In addition, structural damage to the small particles due to the grinding process affects the removal of heavy metals. The treatment effect also differs due to the different nature of some of the heavy metals. For example, the particle size of clinoptilolite has a more obvious effect on the absorption of $\mathrm{Ni}$, and clinoptilolite is a relatively poor remover of $\mathrm{Ni}^{2+}$ in an aqueous solution, which is due to the high stability of the aqueous complex. More $\mathrm{Zn}^{2+}$ was removed, most $\mathrm{Cu}^{2+}$ was removed, and less $\mathrm{Ni}^{2+}$ was removed under the same conditions. The stable macrocomplexes of these metals may be too large to easily enter the zeolite pores.

Another common factor that prevents adsorption by clinoptilolite is ion size. If the ion is larger than the pore, the substance is excluded. The size of the hydration ions of the metals generated the following selective sequence: $\mathrm{Pb}>\mathrm{Ni}>\mathrm{Cu}>\mathrm{Cd}>\mathrm{Zn}>\mathrm{Cr}$.

Finally, earthworms remove heavy metals. The main mechanism by which earthworms remove heavy metal pollution is to reduce oxidative stress using the lipid antioxidase system, chelation, and activation of lysosomes and plasmids to inhibit heavy metal activity.

The variations in the concentrations of different metals can be attributed to the enrichment of heavy metals by earthworms. The concentrations of compounds in organisms are mainly based on absorption, elimination, and biotransformation. Eliminating unnecessary excess metal-to-metal bioaccumulation in sludge is a very important treatment.

The initial absorption of base metals, such as $\mathrm{Cu}$ and $\mathrm{Zn}$, is rapid, and subsequent equilibrium is achieved after several days of exposure, indicating physiological control and possible excretion of these elements by earthworms. External metals, such as $\mathrm{Cd}$, are excreted slowly or are not excreted. The same biological concentration of $\mathrm{Cu}$ in earthworms at all sampling sites resulted in a decrease of the bioaccumulation factor (BAF) in contaminated soil, which may be the result of this mechanism. A low metal concentration in soil corresponds to a high BAF. The excretion of some $\mathrm{Zn}$ by earthworms helps regulate the concentration of metal ions, and BAF is low in most contaminated soils, even at very high $\mathrm{Zn}$ concentrations. Eisenia fetida earthworms accumulated some $\mathrm{Ni}$ in this study, but only a small amount. The BAFs of the five heavy metals in E. fetida were ranked as $\mathrm{Cd}>\mathrm{Zn}>\mathrm{Cu}>\mathrm{Ni}>\mathrm{Pb}$. 


\section{Sludge Composting Conditions and General Methods for Reducing Heavy Metal Hazards}

The compost structure, ventilation, nutrient balance, water content [61], particle size, $\mathrm{pH}$, soluble salts, stability, weeds, heavy metals, phytotoxic compounds and the presence of foreign matter affect compost [62].

\section{$3.1 \mathrm{PH}$}

$\mathrm{pH}$ is an important parameter affecting the composting process.

High $\mathrm{pH}$ values can inhibit microbial growth [63]. The optimal $\mathrm{pH}$ for bacterial growth ranges from 6.0 to 9.0 , and the optimal $\mathrm{pH}$ for fungal growth ranges from 5.5 to 8.0 [64]. The maximum growth and activity of microorganisms are conducive to rapid aerobic composting of sludge [63]. Microorganisms are an important factor affecting the leaching of heavy metals when their activities are enhanced [65].

\subsection{Water Content and Temperature}

The water content of sludge compost should be controlled between $40 \%$ and $60 \%$, and the temperature should be about $55^{\circ} \mathrm{C}$. A turning frequency of more than once per week effectively promotes the efficiency of composting [63].

The concentrations of some heavy metals in sludge composting decrease due to the solubility of water [66].

Leached metal contents decrease with an increase in temperature, and accumulate significantly in the solid phase. The metal form effectively migrates to a minimally toxic or non-toxic state, which activates pathogens and microbial activities $[63,67]$.

\subsection{Other Conditions}

Ventilation is another important condition. Adequate ventilation and optimum humidity, as well as the removal of excess water from metabolic activities and the supply of adequate oxygen are important [68]. Maximum airflow shortens composting time and improves reactor capacity [62]. The ratio of carbon to nitrogen and carbon to phosphorus has a tremendous effect on fermentation. It is generally believed that the best $\mathrm{C} / \mathrm{N}$ ratio for sludge compost is 20-35: 1 . Sludge is rich in phosphorus, and the appropriate $\mathrm{C} / \mathrm{P}$ for heap fertilizer is 75-150: 1 . The average suitable particle size for compost material is $12-60 \mathrm{~mm}$, and the optimal particle size varies with the physical characteristics of the waste. Organic matter content affects the temperature and ventilation and oxygen supply requirements of the heap, and the most suitable organic matter content of heap is $20 \%-80 \%$.

Good composting products can be obtained with high microbial activity, fast composting efficiency, and a short composting cycle when the $\mathrm{pH}$ value is $6-8$, water content is $40 \%-60 \%$, the temperature is controlled at $55^{\circ} \mathrm{C}, \mathrm{C} / \mathrm{N}$ is $20-35: 1$, the $\mathrm{C} / \mathrm{P}$ is $75-150: 1$, and oxygen and organic content is $20 \%-80 \%$. Among these factors, the $\mathrm{pH}$ value, water content, and temperature affect the removal of heavy metals from sludge. As the main factor determining heavy metal leaching, and an increase in $\mathrm{pH}$ reduces soluble heavy metal concentrations; thus, reducing bioavailability. The solubility of water is used to reduce the concentration of some heavy metals. The increase in temperature leads to increased metal leaching and the metal migrates to a state of minimal toxicity or non-toxicity. To sum up, various sludge compost parameters play a role in reducing heavy metal toxicity. Appropriate parameters combined with the use of conditioning agents can reduce the dosage; thus, reducing the environmental pollution.

\section{Future Recommendations}

Research shows that the toxicity of heavy metals decreases gradually after sludge composting. Due to the rapid development of the sewage treatment industry and the progress in sludge treatment technology, $\mathrm{Cu}$, $\mathrm{Zn}, \mathrm{Cd}$, and other heavy metal contents in sludge are reduced. Therefore, after the heavy metals in the sludge 
compost are passivated, the harm to the soil will also be reduced, but there are still some problems that need to be resolved.

The development of new multifunctional conditioning agents will be a trend of future research because of environmental risk and an unstable repair effect. The remediation of heavy metals during sludge composting is affected by many factors. Notably, a single conditioning agent only has a significant impact on a small number of heavy metals in the sludge. However, the use of a variety of conditioning agents, such as lime and clay minerals, will have a great influence on the repair effect. Therefore, it is important to develop multi-functional conditioning agents for various heavy metals to reduce the cost and improve the practical effect.

\section{Conclusion}

This review systematically analyzes and summarizes the effects of conditioning agents on the concentration and morphology of heavy metals during sludge composting. Adding conditioning agents to the composting process greatly reduces the harmful effects of heavy metals during sludge composting. Swelling agents, such as calcium oxide, zeolite, and biochar, are good loose fertilizers that decrease the concentration of heavy metals in sludge and passivate zeolite to reduce the mobility of heavy metals. biochar treatment promotes the passivation of heavy metals, particularly $\mathrm{Pb}$. Zeolite can effectively significantly reduce the unstable $\mathrm{Zn}$. treatment with earthworms not only optimizes the soil but reduces the concentrations of heavy metals, such as $\mathrm{Cu}, \mathrm{Cd}, \mathrm{Cr}, \mathrm{Pb}$, and $\mathrm{Zn}$. The removal rate of $\mathrm{Cu}, \mathrm{Zn}, \mathrm{Cd}, \mathrm{Cr}$ and Ni could reach $27 \%, 40 \%-46 \%, 31.08 \%, 10 \%-15 \%$ and $50 \%-55 \%$ by adding conditioning agents.

Most experiments now use a single conditioning agent, but different conditioning agents have different abilities to remove heavy metals, so they can be used in combination or new conditioning agents can be developed to remove many kinds of heavy metals, but also not cancel the original advantages. This is one direction for the future.

Funding Statement: The study was financially supported by the National Natural Science Foundation of China (41371464), the Study Abroad Fund of Yangtze University, the Study Fund of Engineering Research of Ecology and Agricultural Use of Wetland, the Ministry of Education, Huangshi city Project for Institute Development (HL20181201), the Technical Innovation Project (Major Project) of Hubei Province, China (2016ACA176), and the Scientific Research Project of Hubei Polytechnic University (16xjz04R).

Conflicts of Interest: The authors declare that they have no conflicts of interest to report regarding the present study.

\section{References}

1. Sun, Y. Z., Chen, M., Liu, H., Zhu, Y., Wang, D. B. et al. (2020). Adsorptive removal of dye and antibiotic from water with functionalized zirconium-based metal organic framework and graphene oxide composite nanomaterial Uio-66-(OH)2/GO. Applied Surface Science, 525, 146614. DOI 10.1016/j.apsusc.2020.146614.

2. Chen, M., Sun, Y., Liang, J., Zeng, G. M., Li, Z. W. et al. (2019). Understanding the influence of carbon nanomaterials on microbial communities. Environment International, 126(10), 690-698. DOI 10.1016/j. envint.2019.02.005.

3. Zhang, Q. G., Hu, J. J., Lee, D. J., Chang, Y. J., Lee, Y. J. (2017). Sludge treatment: Current research trends. Bioresource Technology, 243(30), 1159-1172. DOI 10.1016/j.biortech.2017.07.070.

4. Zhan, T. L., Zhan, X. J., Lin, W. A., Luo, X. Y., Chen, Y. M. (2014). Field and laboratory investigation on geotechnical properties of sewage sludge disposed in a pit at Changan landfill, Chengdu, China. Engineering Geology, 170, 24-32. DOI 10.1016/j.enggeo.2013.12.006. 
5. Song, U., Lee, E. J. (2010). Environmental and economical assessment of sewage sludge compost application on soil and plants in a landfill. Resources Conservation and Recycling, 54(12), 1109-1116. DOI 10.1016/j. resconrec.2010.03.005.

6. Zhang, S., Wang, F., Mei, Z. Y., Lv, L. K., Chi, Y. (2020). Status and development of sludge incineration in China. Waste and Biomass Valorization, 12(7), 3541-3574. DOI 10.1007/s12649-020-01217-9.

7. Stefanakis, A. I., Komilis, D. P., Tsihrintzis, V. A. (2011). Stability and maturity of thickened wastewater sludge treated in pilot-scale sludge treatment wetlands. Water Research, 45(19), 6441-6452. DOI 10.1016/j. watres.2011.09.036.

8. Hu, Y. Y., Xu, F. Y., Chen, X., Bao, B. (2019). Research progress on resource utilization of municipal sludge. Meteorological and Environmental Research, 10(2), 64-66. DOI 10.19547/j.issn2152-3940.2019.02.012.

9. Zheng, G. D., Wang, X. K., Chen, T. B., Yang, J., Yang, J. X. et al. (2020). Passivation of lead and cadmium and increase of the nutrient content during sewage sludge composting by phosphate amendments. Environmental Research, 185, 9. DOI 10.1016/j.envres.2020.109431.

10. Chen, Y. N., Liu, Y., Li, Y. P., Wu, Y. X., Chen, Y. R. et al. (2017). Influence of biochar on heavy metals and microbial community during composting of river sediment with agricultural wastes. Bioresource Technology, 243, 347-355. DOI 10.1016/j.biortech.2017.06.100.

11. Duan, Y. M., Awasthi, S. K., Liu, T., Zhang, Z. Q., Awasthi, M. K. (2019). Evaluation of integrated biochar with bacterial consortium on gaseous emissions mitigation and nutrients sequestration during pig manure composting. Bioresource Technology, 291, 121880. DOI 10.1016/j.biortech.2019.121880.

12. Chen, M., Xu, P., Zeng, G. M., Yang, C. P., Huang, D. W. et al. (2015). Bioremediation of soils contaminated with polycyclic aromatic hydrocarbons, petroleum, pesticides, chlorophenols and heavy metals by composting: Applications, microbes and future research needs. Biotechnology Advances, 33(6), 745-755. DOI 10.1016/j. biotechadv.2015.05.003.

13. Sayara, T., Basheer-Salimia, R., Hawamde, F., Sanchez, A. (2020). Recycling of organic wastes through composting: Process performance and compost application in agriculture. Agronomy-Basel, 10(11), 1838. DOI 10.3390/agronomy10111838.

14. Korca, B., Demaku, S. (2021). Assessment of contamination with heavy metals in environment: Water, STERILE, sludge and soil around Kishnica landfill. Kosovo Polish Journal of Environmental Studies, 30(1), 671-677. DOI $10.15244 /$ pjoes/122448.

15. Chen, X. M., Zhao, Y., Zhang, C., Zhang, D. Y., Yao, C. H. et al. (2020). Speciation, toxicity mechanism and remediation ways of heavy metals during composting: A novel theoretical microbial remediation method is proposed. Journal of Environmental Management, 272(1-3), 111109. DOI 10.1016/j.jenvman.2020.111109.

16. Wyrwicka, A., Urbaniak, M. (2018). The biochemical response of willow plants (Salix viminalis L.) to the use of sewage sludge from various sizes of wastewater treatment plant. Science of Total Environment, 615(6), 882-894. DOI 10.1016/j.scitotenv.2017.10.005.

17. Chen, L. M., Liao, Y. F., Ma, X. Q., Lu, S. G. (2020). Heavy metals chemical speciation and environmental risk of bottom slag during co-combustion of municipal solid waste and sewage sludge. Journal of Cleaner Production, 262(10), 121318. DOI 10.1016/j.jclepro.2020.121318.

18. Farsang, A., Babcsanyi, I., Ladanyi, Z., Perei, K., Bodor, A. et al. (2020). Evaluating the effects of sewage sludge compost applications on the microbial activity, the nutrient and heavy metal content of a Chernozem soil in a field survey. Arabian Journal of Geosciences, 13(19), 982. DOI 10.1007/s12517-020-06005-2.

19. Mohamed, B., Mounia, K., Aziz, A., Ahmed, H., Rachid, B. et al. (2018). Sewage sludge used as organic manure in Moroccan sunflower culture: Effects on certain soil properties, growth and yield components. Science of Total Environment, 627, 681-688. DOI 10.1016/j.scitotenv.2018.01.258.

20. Picariello, E., Pucci, L., Carotenuto, M., Libralato, G., Lofrano, G. et al. (2021). Compost and sewage sludge for the improvement of soil chemical and biological quality of mediterranean agroecosystems. Sustainability, 13(1), 26. DOI 10.3390/su13010026. 
21. Deng, W. W., Zhang, A. Y., Chen, S. Y., He, X. P., Jin, L. et al. (2020). Heavy metals, antibiotics and nutrients affect the bacterial community and resistance genes in chicken manure composting and fertilized soil. Journal of Environmental Management, 257(1), 109980. DOI 10.1016/j.jenvman.2019.109980.

22. Liang, C., Das, K. C., McClendon, R. W. (2013). The influence of temperature and moisture contents regimes on the aerobic microbial activity of a biosolids composting blend. Bioresource Technology, 86(2), 131-137. DOI 10.1016/S0960-8524(02)00153-0.

23. Huang, C., Zeng, G. M., Huang, D. L., Lai, C., Xu, P. et al. (2017). Effect of Phanerochaete chrysosporium inoculation on bacterial community and metal stabilization in lead-contaminated agricultural waste composting. Bioresource Technology, 243, 294-303. DOI 10.1016/j.biortech.2017.06.124.

24. Latosinska, J., Czapik, P. (2020). The ecological risk assessment and the chemical speciation of heavy metals in ash after the incineration of municipal sewage sludge. Sustainability, 12(16), 6517. DOI 10.3390/su12166517.

25. Zhou, H. M., Meng, H. B., Zhao, L. X., Shen, Y. J., Hou, Y. Q. et al. (2018). Effect of biochar and humic acid on the copper, lead, and cadmium passivation during composting. Bioresource Technology, 258(12), 279-286. DOI 10.1016/j.biortech.2018.02.086.

26. Huang, D. L., Xu, J. J., Zeng, G. M., Lai, C., Yuan, X. Z. et al. (2015). Influence of exogenous lead pollution on enzyme activities and organic matter degradation in the surface of river sediment. Environmental Science and Pollution Research, 22(15), 11422-11435. DOI 10.1007/s11356-015-4375-0.

27. Lu, J. Y., Wang, X. M., Liu, H. Q., Yu, H. Q., Li, W. W. (2019). Optimizing operation of municipal wastewater treatment plants in China: The remaining barriers and future implications. Environment International, 129, 273-278. DOI 10.1016/j.envint.2019.05.057.

28. Zhang, Z. Y., Ju, R., Zhou, H. T., Chen, H. W. (2021). Migration characteristics of heavy metals during sludge pyrolysis. Waste Management, 120, 25-32. DOI 10.1016/j.wasman.2020.11.018.

29. Li, B. B., Ding, S. X., Fan, H. H., Ren, Y. (2021). Experimental investigation into the effect of pyrolysis on chemical forms of heavy metals in sewage sludge biochar (SSB), with brief ecological risk assessment. Materials, 14(2), 13. DOI 10.3390/ma14020447.

30. Azari, P., Bostani, A. A. (2017). Reducing as availability in calcareous soils using nanoscale zero valent iron. Environmental Science and Pollution, 24(25), 20438-20445. DOI 10.1007/s11356-017-9447-x.

31. Zheng, G. D., Gao, D., Chen, T. B., Luo, W. (2007). Stabilization of nickel and chromium in sewage sludge during aerobic composting. Journal of Hazardous Materials, 142(1-2), 216-221. DOI 10.1016/j.jhazmat.2006.08.003.

32. Sanchez-Monedero, M. A., Cayuela, M. L., Roig, A., Jindo, K., Mondini, N. (2018). Role of biochar as an additive in organic waste composting. Bioresource Technology, 247(6), 1155-1164. DOI 10.1016/j.biortech.2017.09.193.

33. Guo, X. X., Liu, H. T., Zhang, J. (2020). The role of biochar in organic waste composting and soil improvement: A review. Waste Management, 102, 884-899. DOI 10.1016/j.wasman.2019.12.003.

34. Mudhoo, A., Ramasamy, D. L., Bhatnagar, A., Usman, M., Sillanpaa, M. (2020). An analysis of the versatility and effectiveness of composts for sequestering heavy metal ions, dyes and xenobiotics from soils and aqueous milieus. Ecotoxicology and Environmental Safety, 197(22-24), 110587. DOI 10.1016/j.ecoenv.2020.110587.

35. Soudejani, H. T., Kazemian, H., Inglezakis, V. J., Zorpas, A. A. (2019). Application of zeolites in organic waste composting: A review. Biocatalysis and Agricultural Biotechnology, 22(7), 101396. DOI 10.1016/j. bcab.2019.101396.

36. Youssef, N. H., Al-Huqail, A. A., Ali, H. M., Abdelsalam, N. R., Sabra, M. A. (2020). The role of Serendipita indica and Lactobacilli mixtures on mitigating mycotoxins and heavy metals' risks of contaminated sewage sludge and its composts. Scientific Reports, 10(1), 15159. DOI 10.1038/s41598-020-71917-8.

37. Jiang, Y., Shang, Y., Gong, T. J., Hu, Z. X., Yang, K. et al. (2020). High concentration of $\mathrm{Mn}^{2+}$ has multiple influences on aerobic granular sludge for aniline wastewater treatment. Chemosphere, 240, 124945. DOI 10.1016/j.chemosphere.2019.124945.

38. Chaturvedi, A. D., Pal, D., Penta, S., Kumar, A. (2015). Ecotoxic heavy metals transformation by bacteria and fungi in aquatic ecosystem. World Journal of Microbiology \& Biotechnology, 31(10), 1595-1603. DOI 10.1007/s11274-015-1911-5. 
39. Mantovi, P., Baldoni, G., Toderi, G. (2005). Reuse of liquid, dewatered, and composted sewage sludge on agricultural land: Effects of long-term application on soil and crop. Water Research, 39(2-3), 289-296. DOI 10.1016/j.watres.2004.10.003.

40. Tessier, A. P., Campbell, P. G. C., Bisson, M. X. (1979). Sequential extraction procedure for the speciation of particulate trace metals. Rights \& Permissions, 51(7), 844-851. DOI 10.1021/ac50043a017.

41. Nomeda, S., Valdas, P., Chen, S. Y., Lin, J. G. (2008). Variations of metal distribution in sewage sludge composting. Waste Management, 28(9), 1637-1644. DOI 10.1016/j.wasman.2007.06.022.

42. Ignatowicz, K. (2017). The impact of sewage sludge treatment on the content of selected heavy metals and their fractions. Environmental Research, 156(3), 19-22. DOI 10.1016/j.envres.2017.02.035.

43. Bozym, M., Siemiatkowski, G. (2018). Characterization of composted sewage sludge during the maturation process: A pilot scale study. Environmental Science and Pollution Research, 25(34), 34332-34342. DOI 10.1007/s11356-018-3335-X.

44. Liu, Y. S., Ma, L. L., Li, Y. Q., Zheng, L. T. (2007). Evolution of heavy metal speciation during the aerobic composting process of sewage sludge. Chemosphere, 67(5), 1025-1032. DOI 10.1016/j.chemosphere.2006.10.056.

45. Wang, X. K., Zheng, G. D., Chen, T. B., Shi, X. X., Wang, Y. W. et al. (2019). Effect of phosphate amendments on improving the fertilizer efficiency and reducing the mobility of heavy metals during sewage sludge composting. Journal of Environmental Management, 235, 124-132. DOI 10.1016/j.jenvman.2019.01.048.

46. Liu, H. T., Guo, X. X. (2019). Hydroxyapatite reduces potential Cadmium risk by amendment of sludge compost to turf-grass grown soil in a consecutive two-year study. Science of Total Environment, 661(74), 48-54. DOI 10.1016/ j.scitotenv.2019.01.053.

47. Chen, Y. R., Chen, Y. N., Li, Y. P., Wu, Y. X., Zeng, Z. P. et al. (2019). Changes of heavy metal fractions during cocomposting of agricultural waste and river sediment with inoculation of Phanerochaete chrysosporium. Journal of Hazardous Materials, 378, 120757. DOI 10.1016/j.jhazmat.2019.120757.

48. Zorpas, A. A., Inglezakis, V. J., Loizidou, M. (2008). Heavy metals fractionation before, during and after composting of sewage sludge with natural zeolite. Waste Management, 28(11), 2054-2060. DOI 10.1016/j. wasman.2007.09.006.

49. Wong, J. W. C., Selvam, A. (2006). Speciation of heavy metals during co-composting of sewage sludge with lime. Chemosphere, 63(6), 980-986. DOI 10.1016/j.chemosphere.2005.08.045.

50. Nissen, L. R., Lepp, N. W., Edwards, R. (2000). Synthetic zeolites as amendments for sewage sludge-based compos. Chemosphere, 41(1-2), 265-269. DOI 10.1016/S0045-6535(99)00420-8.

51. Zorpas, A. A., Vassilis, I., Loizidou, M., Grigoropoulou, H. (2002). Particle size effects on uptake of heavy metals from sewage sludge compost using natural zeolite clinoptilolite. Journal of Colloid and Interface Science, 250(1), 1-4. DOI 10.1006/jcis.2002.8246.

52. Zorpas, A. A., Constantinides, T., Vlyssides, A. G., Haralambous, I., Loizidou, M. (2000). Heavy metal uptake by natural zeolite and metals partitioning in sewage sludge compost. Bioresource Technology, 72(2), 113-119. DOI 10.1016/S0960-8524(99)00110-8.

53. Liu, W., Huo, R., Xu, J. X., Liang, S. X., Li, J. J. et al. (2017). Effects of biochar on nitrogen transformation and heavy metals in sludge composting. Bioresource Technology, 235(2), 43-49. DOI 10.1016/j.biortech.2017.03.052.

54. Awasthi, M. K., Wang, Q., Huang, H., Li, R. H., Shen, F. et al. (2016). Effect of biochar amendment on greenhouse gas emission and bio-availability of heavy metals during sewage sludge co-composting. Journal of Cleaner Production, 135, 829-835. DOI 10.1016/j.jclepro.2016.07.008.

55. Wang, X. J., Chen, L. X., Xia, S. Q., Zhao, J. F. (2008). Changes of Cu, Zn, and Ni chemical speciation in sewage sludge co-composted with sodium sulfide and lime. Journal of Environmental Sciences, 20(2), 156-160. DOI 10.1016/S1001-0742(08)60024-8.

56. Liu, F., Zhu, P. F., Sheng, W., Xue, J. P. (2013). Sludge earthworm composting technology by Eisenia fetida. Journal of Material Cycles and Waste Management, 15(4), 482-488. DOI 10.1007/s10163-013-0157-2.

57. Bakar, A., Mahmood, N. Z., Silva, J. A., Abdullah, N., Jamaludin, A. A. (2011). Vermicomposting of sewage sludge by Lumbricus rubellus using spent mushroom compost as feed material: Effect on concentration of heavy metals. Biotechnology and Bioprocess Engineering, 16(5), 1036-1043. DOI 10.1007/s12257-011-0147-y. 
58. Jiang, Y., Liu, Y., Zhang, H. N., Yang, K., Li, J. Y. et al. (2020). Aerobic granular sludge shows enhanced resistances to the long-term toxicity of $\mathrm{Cu}(\mathrm{II})$. Chemosphere, 253, 126664. DOI 10.1016/j. chemosphere.2020.126664.

59. Zhang, C., Yang, K. M., Li, Y., Cheng, F., Rong, K. P. (2019). Spectral characteristics and the study of pollution degree of maize leaves under copper and lead stress. Journal of the Indian Society of Remote Sensing, 48(1), 2133. DOI 10.1007/s12524-019-01055-w.

60. Yuan, Y. N., Chai, L. Y., Yang, Z. H., Wu, R. P., Liu, H. (2017). Immobilization of Cd and Pb in soils by polymeric hydroxyl ferric phosphate. Transactions of Nonferrous Metals Society of China, 27(5), 1165-1171. DOI 10.1016/ S1003-6326(17)60136-5.

61. Stocks C., Barker A. J., Guy S. (2002). The composting of brewery sludge. Journal of the Institute of Brewing, 108(4), 452-458. DOI 10.1002/j.2050-0416.2002.tb00575.x.

62. Wei, Y. S., Fan, Y. B., Wang, M. J., Wang, J. S. (2000). Composting and compost application in China. Resources, Conservation and Recycling, 30(4), 277-300. DOI 10.1016/S0921-3449(00)00066-5.

63. Khalil, A. I., Hassouna, M. S., El-Ashqar, H. M. A., Fawzi, M. (2011). Changes in physical, chemical and microbial parameters during the composting of municipal sewage sludge. World Journal of Microbiology and Biotechnology, 27(10), 2359-2369. DOI 10.1007/s11274-011-0704-8.

64. Villar, P., Villar, M., Callejón, M., Pérez, J. L., Jiménez, J. C. et al. (2009). Evolution of polycyclic aromatic hydrocarbons (PAHs) and heavy metals in sludge samples from conventional activated sludge wastewater treatment plants. Environmetrics, 20(5), 561-574. DOI 10.1002/env.954.

65. Fang, W., Wei, Y. H., Liu, J. G., Kosson, D. S., van der Sloot, H. A. et al. (2016). Effects of aerobic and anaerobic biological processes on leaching of heavy metals from soil amended with sewage sludge compost. Waste Management, 58(1), 324-334. DOI 10.1016/j.wasman.2016.07.036.

66. Kouki, S., Saidi, N., M'hiri, F., Hafiane, A., Hassen, A. (2016). Co-Composting of macrophyte biomass and sludge as an alternative for sustainable management of constructed wetland by-products. Clean-Soil Air Water, 44(6), 694-702. DOI 10.1002/clen.201500346.

67. Zhang, Z. P., Baroutian, S., Munir, M. T., Young, B. R. (2017). Variation in metals during wet oxidation of sewage sludge. Bioresource Technology, 245(A), 234-241. DOI 10.1016/j.biortech.2017.08.164.

68. Kästner, M., Miltner, A. (2016). Application of compost for effective bioremediation of organic contaminants and pollutants in soil. Applied Microbiology and Biotechnology, 100(8), 3433-3449. DOI 10.1007/s00253-016-7378-y. 